\title{
First record of Macrobrachium grandimanus (Randall, 1840) (Crustacea, Decapoda, Palaemonidae) from Guam, Micronesia
}

\author{
Yusuke Fuke $^{1 *}$, Makoto Sasazuka² \\ 1 Laboratory of Animal Ecology, Graduate School of Science, Kyoto University, Kyoto, Japan •yfa73986@gmail.com ( https://orcid.org/0000- \\ 0001-6404-6241 \\ 2 One's habitat, Tokyo, Japan • ones.habitat@gmail.com \\ * Corresponding author
}

\begin{abstract}
The Hawaiian River Shrimp, Macrobrachium grandimanus (Randall, 1840), is an amphidromous brackish water prawn that occurs in the Hawaiian Islands (type locality), Ryukyu Islands, Melanesia (Fiji, New Caledonia), and Polynesia (Tonga). Two genetically and morphologically differentiated lineages of this species are known, i.e., the Hawaiian and the Ryukyuan lineages. Here, we report a new record of this species from Guam, Micronesia. Morphological and mitochondrial DNA analyses revealed that the Guam population is closely related to the Ryukyu lineage.
\end{abstract}

Keywords

Amphidromous, Decapoda, DNA barcoding, haplotype network, mitochondrial DNA, Ryukyu Archipelago

Academic editor: Nasreen Peer | Received 18 January 2021 | Accepted 3 May 2021 | Published 11 May 2021

Citation: Fuke Y, Sasazuka M (2021) First record of Macrobrachium grandimanus (Randall, 1840) (Crustacea, Decapoda, Palaemonidae) from Guam, Micronesia. Check List 17 (3): 759-763. https://doi.org/10.15560/17.3.759

\section{Introduction}

The Hawaiian River Shrimp, Macrobrachium grandimanus (Randall, 1840), is a brackish-water prawn that is widely distributed in the Pacific Islands and has an amphidromous life history (Shokita 1985). Macrobrachium grandimanus is known to be distributed in the Hawaiian Islands (type locality), Ryukyu Islands, Melanesia (Fiji, New Caledonia), and Polynesia (Tonga) (Kubo 1940; Holthuis 1950; Maciolek and Yamada 1981; Shokita 1985; Short and Marquet 1998; Fig. 1). The Hawaii and Ryukyu populations are distinctly diverged based on genetic and morphology; since the type locality of the species is Hawaii, the Ryukyu population is considered a cryptic species (Holthuis 1950; Liu et al. 2007). However, the distributional range of each lineage remains unknown because comparisons have not been performed in other regional populations. To resolve the taxonomic confusion of this species, it is necessary to compare different populations from various localities. Here, we report the first record of $M$. grandimanus from Guam, Micronesia, and reveal that the specimens are genetically and morphologically clustered with the population from the Ryukyu Islands.

\section{Methods}

Seven specimens of $M$. grandimanus were collected from the Hagåtña (Agana) River, Guam (Fig. 2), and 14 specimens from Ishigaki-jima Island, Ryukyu Islands, Japan, 


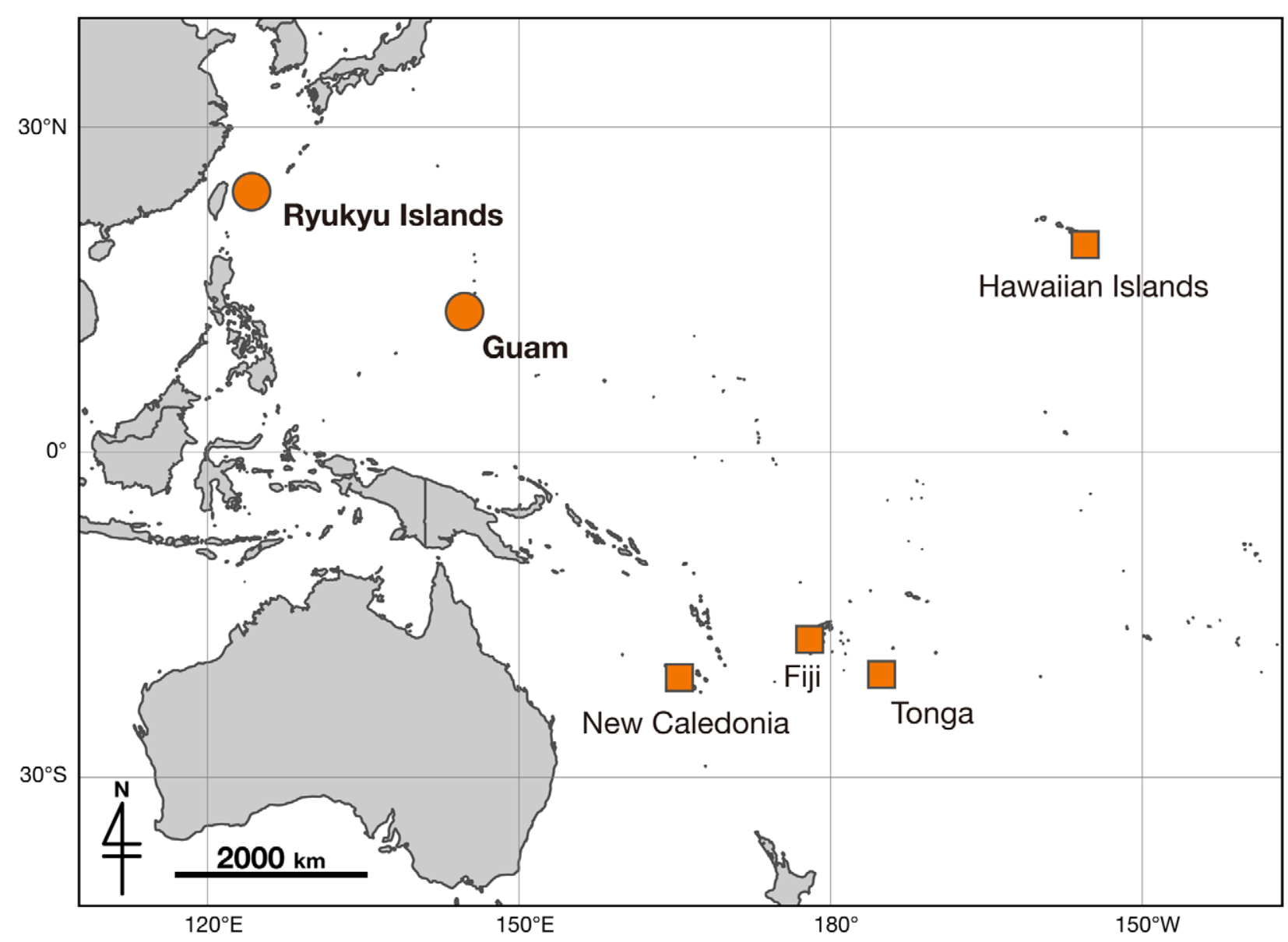

Figure 1. Distribution map of Macrobrachium grandimanus. Circles represent the collection sites of specimens used in this study, and squares represent distribution records based on literature records.

for genetic and morphological comparisons. Hand nets were used for collection. All samples were preserved in $70 \%$ ethanol. The examined specimens were deposited in the Zoological Collection of Kyoto University, Japan (KUZ).

Measurements were performed for postorbital carapace length (CL), and segment of the 1st to 3rd pereiopods with digital calipers (CD67-S20PM, Mitutoyo, Japan) after preservation.

Total DNA was extracted from the 4th or 5th pleopod using a Genomic DNA Purification kit (Promega, USA). A fragment of the mitochondrial 16S rRNA gene was polymerase chain reaction (PCR)-amplified using the primer pair $16 \mathrm{sA}\left(5^{\prime}\right.$-ACT TGA TAT ATA ATT AAA GGG CCG-3') and 16sB (5'-CTG GCG CCG GTC TGA ACT CAA ATC-3') (Wowor et al. 2009). The PCR amplification conditions were as follows: initial denaturation $\left(94{ }^{\circ} \mathrm{C}, 2 \mathrm{~min}\right) ; 30$ cycles of denaturation $(94$ $\left.{ }^{\circ} \mathrm{C}, 30 \mathrm{~s}\right)$, annealing $\left(52^{\circ} \mathrm{C}, 30 \mathrm{~s}\right)$, and extension $\left(72{ }^{\circ} \mathrm{C}\right.$, $60 \mathrm{~s})$; and a single final extension $\left(72{ }^{\circ} \mathrm{C}, 7 \mathrm{~min}\right)$. The PCR products were purified with Illustra ExoStar (GE Healthcare Japan, Japan) and sequenced on ABI 3130xl Genetic Analyzer (Applied Biosystems, USA) using amplification primer and the BigDye Terminator Cycle sequencing FS Ready Reaction Kit v. 3.1 (Applied Biosystems). The partial 16S rRNA sequences were deposited in the DDBJ/EMBL/GenBank (accession numbers:

\section{LC530806-LC530812, LC569848-LC569861).}

Sequences of the Hawaiian and Ryukyuan M. grandimanus specimens were obtained from the International Nucleotide Sequence Database and added to the following analysis (DQ194925 and DQ194926; Liu et al. 2007). Multiple alignments were performed using MAFFT (Katoh and Standley 2013) on Unipro UGENE (Okonechnikov et al. 2012) for the obtained sequences. To visualize the relationships between local populations, the haplotype network was estimated using PopART (Leigh and Bryant 2015) based on the TCS algorithm (Clement et al. 2000).

\section{Results}

Order Decapoda

Family Palaemonidae Rafinesque, 1815

Genus Macrobrachium Spence Bate, 1868

\section{Macrobrachium grandimanus (Randall, 1840)}

Material examined. GUAM - Hagåtña River estuary, Hagåtña; 13.4775, 144.7545; 18.XI.2018; Makoto Sasazuka leg.; under a rock; 4ก̂, 3ㅇ; CL 6.5-10.9 mm; KUZ Z3780; GenBank: LC530806-LC530812.

JAPAN • Toro River, Ishigaki-jima Island, Okinawa, Ryukyu Islands; 24.4647, 124.2499; 12.III.2020; Yusuke Fuke leg.; roots of mangrove; 7ðे, 7우 CL 6.0-13.7 mm; 

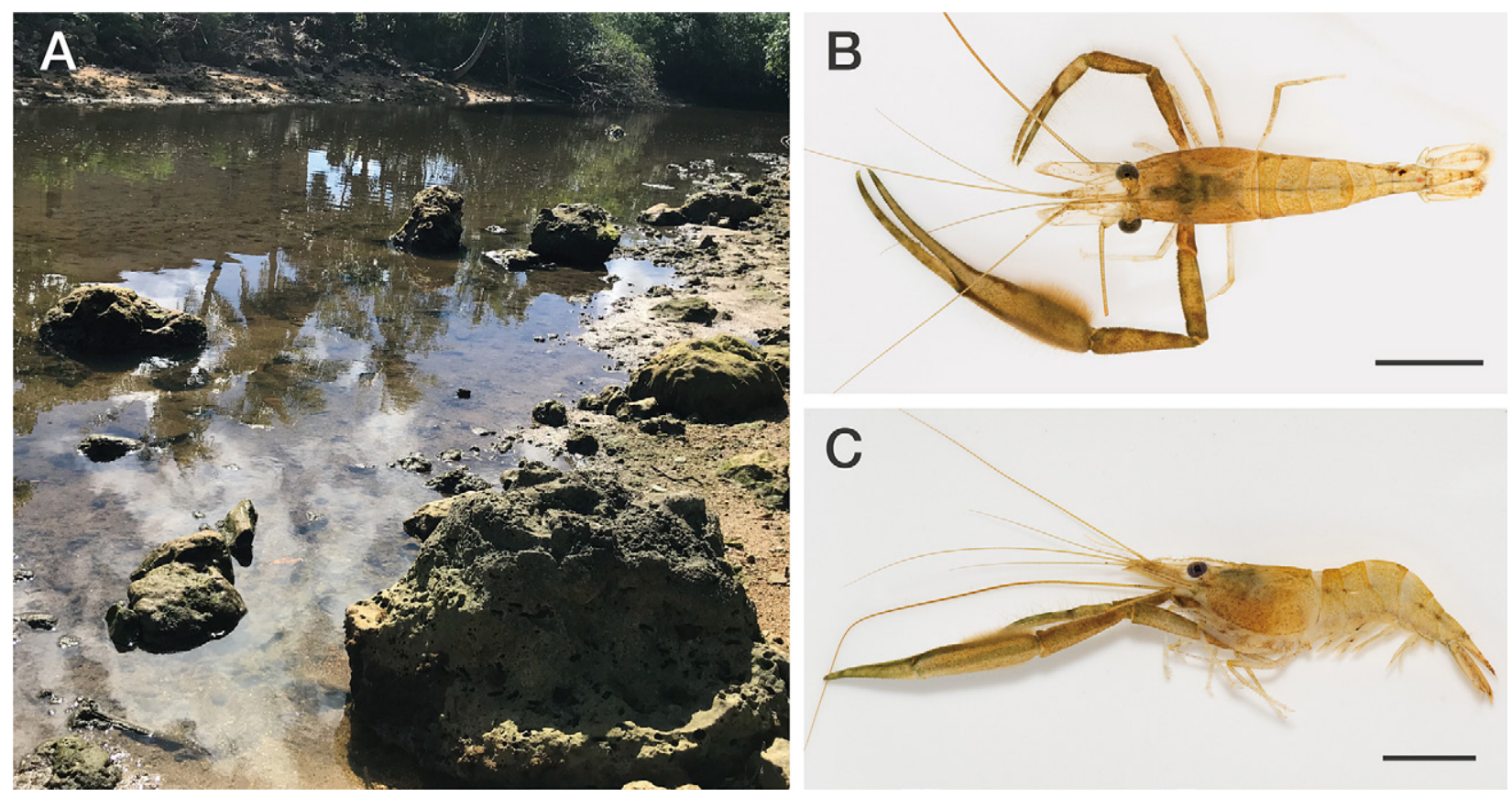

Figure 2. Macrobrachium grandimanus collected from Guam (male, CL 10.9 mm, KUZ Z3780) and its habitat. A. Habitat of M. grandimanus in Guam. B. Dorsal view. C. Lateral view. Scale bars: B, C $=10 \mathrm{~mm}$.

\section{KUZ Z3781; GenBank: LC569848-LC569861.}

Identification. The specimens collected from Guam were identified as $M$. grandimanus based on morphological characters (Holthuis 1950; Cai and Jeng 2001). Rostrum straight, reaching end of third segment of antennular peduncle; dorsal margin with 13 or 14 teeth, including 3 or 4 on carapace posterior to orbital margin; ventral margin with $2-4$ teeth $(n=7)$. In three adult males, first pereiopod slender; finger $0.7-0.9$ times shorter than palm; palm 0.3-0.4 times shorter than carpus; carpus 1.1-1.2 times longer than merus; merus 1.62.1 times longer than ischium. In one adult male, second pereiopods unequal in shape and size; major second pereiopod (left) robust, longer than total body length; tips of finger curved inwards, finger slightly shorter than palm; surface of palm with dense setae on last $2 / 3$, palm 1.3 times longer than carpus; carpus 1.3 times longer than merus; merus 2.4 times longer than ischium; minor second pereiopod (right) slender; finger 2.1 times longer than palm; palm 0.6 times shorter than carpus; carpus 1.2 times longer than merus; merus 1.7 times longer than ischium (Fig. 2). In two adult males, third pereiopod slender; dactylus 0.3 times shorter than propodus; propodus 1.5-1.8 times longer than carpus; carpus 0.50.6 times shorter than merus; merus $2.1-2.3$ times longer than ischium.

Genetic analysis. We obtained 441 bp of 16S rRNA of M. grandimanus mitochondrial DNA from the Guam population, the Ryukyu population, and including the Hawaii population obtained from the GenBank. Haplotype network analysis revealed two haplotypes from the Guam population and six haplotypes from the Ryukyu population; no haplotypes were shared among the three populations (Fig. 3). There were 14 or 15 base substitutions (3.2-3.4\%) between the Guam and Hawaii populations, and $1-4$ base substitutions $(0.2-0.9 \%)$ between the Guam and Ryukyu populations.

\section{Discussion}

Guam is the largest oceanic island in Micronesia, located at the southern end of the Mariana Islands in the western Pacific Ocean (Fig. 1). It is an unusual island in the Mariana Islands since there are abundant of inland water bodies. At least five species of atyid river shrimp, Antecaridina lauensis (Edmondson, 1935), Atyoida pilipes (Newport, 1847), Caridina variabilis (de Mazancourt, Marquet, Rogers \& Keith, 2018), C. typus (Milne Edwards, 1837), and Halocaridinides sp., and four species of palaemonid river prawn, Macrobrachium equidens (Dana, 1852), M. lar (Fabricius, 1798), M. rosenbergii (De Man, 1879) (as introduced species), and Palaemon debilis (Dana, 1852), have been reported from Guam (Concepcion and Nelson 1999; Leberer and Cai 2003; Paulay et al. 2003; de Mazancourt et al. 2018). All of these species are amphidromous. Some fishes, crustaceans, and snails with amphidromous life histories are known to be dispersed by ocean currents during their larval stages (McDowall 2010; Anger 2013; Abdou et al. 2015). The planktonic larval duration of C. typus, $M$. equidens, M. lar, and P. debilis is $>22,36-53,77-110$, and 20-24 days, respectively (Ngoc-Ho 1976; Shokita 1977; Nakahara et al. 2007; Lal et al. 2014). Macrobrachium grandimanus is also an amphidromous species with small eggs, and its larvae reach decapodid-stage in 27-30 days in the Ryukyu population (Shokita 1985). The length of those larval duration would have been sufficient for those species to reach the oceanic island of Guam; however, for M. grandimanus, it is assumed to be 


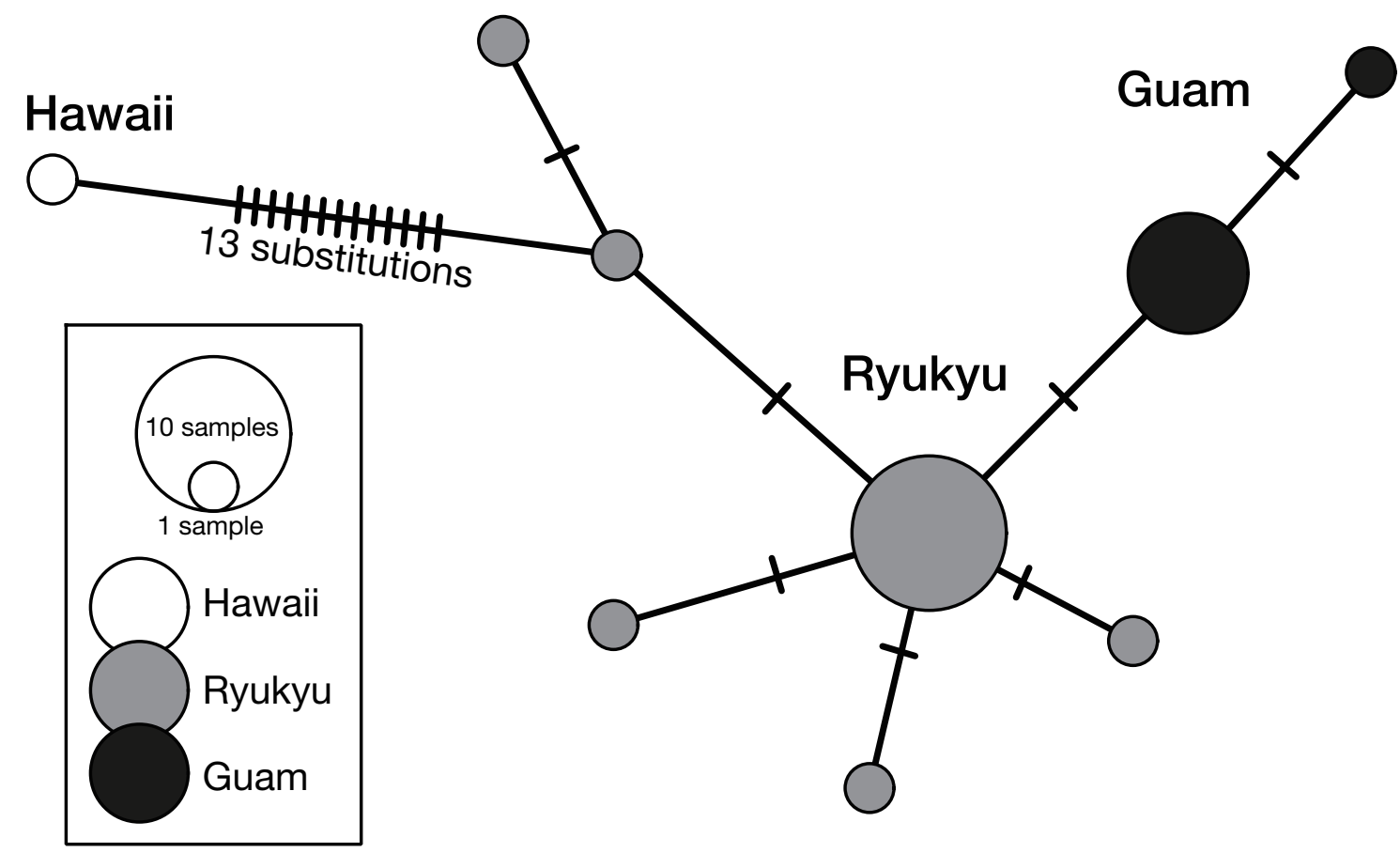

Figure 3. TCS haplotype network of Macrobrachium grandimanus based on 441 bp of $16 \mathrm{~S}$ rRNA mitochondrial DNA. A black bar represents a single base substitution.

too short to facilitate frequent genetic exchange between Hawaii and Guam, and also between Hawaii and the Ryukyu Islands. That this species does not share a haplotype among the three populations may be due to the small sample size or the absence of stepping-stones (i.e., a staging post). To clarify the formation history of the Guam population, higher resolution genomic analysis and confirmation of the presence or absence of this species in the potential staging post, for example, the Philippines are necessary.

Holthuis (1950) highlighted a difference in the rostral formula between the Ryukyuan and Hawaiian M. grandimanus populations (11-15/3 vs. 14-17/4-5, respectively). Furthermore, Lui et al. (2007) conducted a mitochondrial DNA-based phylogenetic analysis of East Asian Macrobrachium species, including M. grandimanus populations from the Hawaii Island and Ryukyu Islands, and reported that this species has a remarkable regional differentiation. Since the type locality of this species is Hawaii, the Ryukyu population is considered to be a pseudocryptic species. The rostral formula in the present Ryukyu population is 12-14/3-5, and Guam population is $13-14 / 2-4$, agreeing with the Ryukyu population. The haplotype network analysis based on mitochondrial DNA also showed close relationship between the Guam and Ryukyu populations (Fig. 3). If the Hawaii and Ryukyu populations are considered to be different species, this Guam population would be attributed to the same species represented by the Ryukyu population. These results are consistent with the direction of the North Equatorial Current and the Kuroshio Current (Chang et al. 2015). Short and Marquet (1998) reported four M. grandimanus individuals from New Caledonia and described the rostral formula as $14-17 / 3-7$, indicating that the New Caledonian population is similar to the Hawaiian population. In the future, it will be necessary to examine morphological traits other than the rostral formula and to make comparisons using genome-wide markers throughout the distribution area. Studies on the taxonomic organization and population development of $M$. grandimanus will provide important insights into the diversity formation of amphidromous migratory organisms in the western Pacific.

\section{Acknowledgements}

We are grateful to Frank Camacho (The University of Guam) and Brent Tibbatts (Guam Department of Agriculture, Division of Aquatic and Wildlife Resources) for providing useful information. We also thank Katsutoshi Watanabe (Kyoto University) for providing the experimental environment.

\section{Authors' Contributions}

MS and YF collected the specimens and discussed and checked the final draft. MS photographed the specimens. YF conducted the genetic and morphological analysis and wrote the manuscript.

\section{References}

Abdou A, Keith P, Galzin R (2015) Freshwater neritids (Mollusca: Gastropoda) of tropical islands: amphidromy as a life cycle, a review. Revue d'Écologie 70: 387-397.

Anger K (2013) Neotropical Macrobrachium (Caridea: Palaemoni- 
dae): on the biology, origin, and radiation of freshwater-invading shrimp. Journal of Crustacean Biology 33: 151-183. https://doi org/10.1163/1937240X-00002124

Cai Y, Jeng MS (2001) On a new species of Macrobrachium Bate, 1868 (Decapoda, Palaemonidae) from northern Taiwan. Crustaceana 74: 275-283. https://doi.org/10.1163/156854001505514

Chang YL, Sheng J, Ohashi K, Béguer-Pon M, Miyazawa Y (2015) Impacts of interannual ocean circulation variability on Japanese eel larval migration in the Western North Pacific Ocean. PLoS ONE 10: e0144423. https://doi.org/10.1371/journal.pone.0144423

Clement M, Posada D, Crandall KA (2000) TCS: a computer program to estimate gene genealogies. Molecular Ecology 9: 1657-1659. https://doi.org/10.1046/j.1365-294x.2000.01020.x

Concepcion GB, Nelson SG (1999) Effects of a dam and reservoir on the distributions and densities of macrofauna in tropical streams of Guam (Mariana Islands). Journal of Freshwater Ecology 14: 447-454. https://doi.org/10.1080/02705060.1999.9663703

Dana JD (1852) Conspectus crustaceorum, \&c. Conspectus of the Crustacea of the exploring expedition under Capt. C. Wilkes, U.S.N. Macroura. Proceedings of the Academy of Natural Sciences of Philadelphia 6: 10-28

de Man JG (1879) On some species of the genus Palaemon Fabr. with descriptions of two new forms. Notes from the Leyden Museum. 41: $165-184$.

de Mazancourt V, Marquet G, Rogers DC, Keith P (2018) Description of a new species of Caridina (Crustacea: Decapoda: Atyidae) from two Micronesian islands (Guam and Babeldaob). Zootaxa 4377: 39. https://doi.org/10.11646/zootaxa.4377.1.3

Edmondson CH (1935) New and rare Polynesian Crustacea. Bernice P. Bishop Museum Occasional Papers 10: 3-40.

Fabricius JC (1798) Entomologia Systematica emendata et aucta, secundum classes, ordines, genera, species adjectis synonimis locis observationibus descriptionibus. Hafniae. I-IV. Supplementum Entomologiae Systematicae. Impensis Christ. Gottl. Proft, Copenhagen: 1-572. https://doi.org/10.5962/bhl.title.122153

Holthuis LB (1950) The Decapoda of the Siboga Expedition. Part X. The Palaemonidae collected by the Siboga and Snellius expeditions with remarks on other species. I. Subfamily Palaemoninae. Siboga Expeditie 39 (a9): 1-268.

Katoh K, Standley DM (2013) MAFFT multiple sequence alignment software version 7: improvements in performance and usability. Molecular Biology and Evolution 30: 772-780. https://doi.org/ $10.1093 / \mathrm{molbev} / \mathrm{mst} 010$

Kubo I (1940) Studies on Japanese Palaemonoid shrimps. I. Palaemon II. Pontoniinae. Journal of the Imperial Fisheries Institute 34: 5-30.

Lal MM, Seeto J, Pickering TD (2014) Complete larval development of the Monkey River Prawn Macrobrachium lar (Palaemonidae) using a novel greenwater technique. SpringerPlus 3, 568. https://doi. org/10.1186/2193-1801-3-568

Leberer T, Cai Y (2003) Shrimps of the family Atyidae from Guam, Mariana Islands. Micronesia 35-36: 353-358.

Leigh JW, Bryant D (2015) POPART: full-feature software for haplotype network construction. Methods in Ecology and Evolution 6: 1110-1116. https://doi.org/10.1111/2041-210X.12410

Liu M, Cai Y, Tzeng C (2007) Molecular systematics of the freshwater prawn genus Macrobrachium Bate, 1868 (Crustacea: Decapoda: Palaemonidae) inferred from mtDNA sequences, with emphasis on East Asian species. Zoological Studies 46: 272-289.

Maciolek J, Yamada R (1981) Vai Lahi and other lakes of Tonga. Verhandlungen des Internationalen Verein Limnologie 21: 693-698.

McDowall RM (2010) Why be amphidromous: expatrial dispersal and the place of source and sink population dynamics? Reviews in Fish Biology and Fisheries 20: 87-100. https://doi.org/10.1007/ s11160-009-9125-2

Milne Edwards H (1837) Histoire naturelle des crustacés, comprenant l'anatomie, la physiologie et la classification de ces animaux. Vol. 2, Encyclopédique. Roret, Paris, 638 pp, pls. 1-14. https://doi. org/10.5962/bhl.title.16170

Nakahara Y, Hagiwara A, Miya Y, Hirayama K (2007) Larval development of three amphidromous shrimp species (Atyidae). Bulletin of the Faculty of Fisheries, Nagasaki University 88: 43-59. [in Japanese with English abstract]

Newport G (1847) Note on the genus Atya of Leach, with descriptions of four apparently new species, in the cabinets of the British Museum. The Annals and Magazine of Natural History (Series 1) 19: 158-160, pl. 8. https://doi.org/10.1080/037454809494502

Ngoc-Ho N (1976) The larval development of the prawns Macrobrachium equidens and Macrobrachium sp. (Decapoda: Palaemonidae), reared in the laboratory. Journal of Zoology 178: 15-55. https://doi.org/10.1111/j.1469-7998.1976.tb02262.x

Okonechnikov K, Golosova O, Fursov M (2012) Unipro UGENE: a unified bioinformatics toolkit. Bioinformatics 28: 1166-1167. https://doi.org/10.1093/bioinformatics/bts091

Paulay G, Kropp R, Ng P, Eldredge L (2003) The crustaceans and pycnogonids of the Mariana Islands. Micronesica 35: 456-513.

Rafinesque CS (1815) Analyse de la nature ou tableau de l'univers et des corps organisés. Self-published, Palermo, 224. https://doi.org/10. 5962/bhl.title.106607

Randall JW (1840) Catalogue of the Crustacea brought by Thomas Nuttall and J.K. Townsend, from the West Coast of North America and the Sandwich Islands, with descriptions of such species as are apparently new, among which are included several species of different localities, previously existing in the collection of the Academy. Journal of the Academy of Natural Sciences at Philadelphia 8: 106-147, pls. 3-7. https://doi.org/10.5962/bhl.title.119921

Shokita S (1977) Larval development of palaemonid prawn, Palaemon (Palaemon) debilis Dana from the Ryukyu Islands. Bulletin of Science \& Engineering Division, University of Ryukyus. Mathematics \& Natural Sciences 23: 57-76.

Shokita S (1985) Larval development of the palaemonid prawn, Macrobrachium grandimanus (Randall), reared in the laboratory, with special reference to larval dispersal. Zoological Science 2: 785-803.

Short JW, Marquet G (1998) New records of freshwater Palaemonidae (Crustacea, Decapoda) from New Caledonia. Zoosystema 20: 401-410.

Spence Bate C (1868) On a new genus, with four new species, of freshwater prawns. Proceedings of the Zoological Society of London 1868: 363-368.

Wowor D, Muthu V, Meier R, Balke M, Cai Y, Ng PKL (2009) Evolution of life history traits in Asian freshwater prawns of the genus Macrobrachium (Crustacea: Decapoda: Palaemonidae) based on multilocus molecular phylogenetic analysis. Molecular Phylogenetics and Evolution 52: 340-350. https://doi.org/10.1016/j.ymp ev.2009.01.002 